\title{
The Best Academic Administration Personnel Selection Model Using the Weighted Sum Model (WSM)
}

\author{
M. Miftakul Amin ${ }^{1, *}$ Yevi Dwitayanti ${ }^{2}$ \\ ${ }^{1}$ Department of Computer Engineering, Politeknik Negeri Sriwijaya, Jl. Srijaya Negara Bukit Besar, Palembang, \\ 30139, Indonesia \\ ${ }^{2}$ Department of Computer Accounting, Politeknik Negeri Sriwijaya, Jl. Srijaya Negara Bukit Besar, Palembang, \\ 30139, Indonesia \\ *Corresponding author. Email: miftakul_a@polsri.ac.id
}

\begin{abstract}
The program for selecting outstanding academic administrative staff is one of the programs organized by the ministry as a reward for the performance of academic administrative staff. This program is carried out in stages from the university level to the national level. This study aims to create a model of a decision support system to determine outstanding academic administrative personnel at the Sriwijaya State Polytechnic. The method used in this study is the Weighted Sum Model (WSM). The WSM method is the simplest and easiest method and is often used in decision support systems. The model built uses 7 criteria, namely 1) educational qualifications, 2) track record of training or training activities, 3) track record of awards/achievements, 4) rank/class, 5) group tenure, 6) self-description value, 7) the value of individual works. From the alternatives to be chosen, this model has succeeded in providing a ranking recommendation of alternatives from the most recommended, marked by the largest to the smallest weight values. The results of this study indicate that the WSM method is quite reliable in completing the selection of academic administrative personnel in universities.
\end{abstract}

Keywords: Decision Support System, Weighted Sum Model (WSM).

\section{INTRODUCTION}

In the management of education there are 4 (four) main elements, namely educators, education staff, students, and learning facilities. Educators are professionals in charge of planning and implementing the learning process, assessing learning outcomes, conducting guidance and training, as well as conducting research and community service. Educational staff are in charge of managing, developing, supervising administration, and technical services to support the educational process. Learning facilities and human resources in the era of the industrial revolution 4.0 must be adapted to the needs and demands of being based on good information and communication technology.

Every year the Director of Science and Technology Resources and Higher Education conducts selection activities for the selection of academic administrative personnel with achievements in state universities and higher education service institutions throughout Indonesia. This selection starts from the internal stage of higher education to the national stage selection.
Academic administrative staff are educational staff as the spearhead in service to students and lecturers as well as other communities in the academic field. Academic administrative staff are expected to be able to provide excellent service in accordance with the rules and also the needs of stakeholders. By holding the election of academic administrative staff with high achievement, it is hoped that it will provide enthusiasm and motivation to academic administrative staff in their work, and always innovate and be creative to improve and improve the efficiency of academic administrative services.

The implementation of the selection of academic administration is carried out in stages, starting from the stages in tertiary institutions and the winners are proposed to the National level so that each university has a programmed reward system for Academic Administration Personnel who have high achievements in carrying out daily work activities at their respective universities. Efforts to recognize achievements resulting from the election can be valuable information for universities as a consideration for prioritizing the development of competitive education personnel [1]. 
The purpose of awarding the Academic Administration Personnel is to give real acknowledgment of commitment, creative, innovative thinking, effort and responsibility in serving academic administrative affairs to help students, study programs/departments/faculty/college and lecturers in implementing learning efficiently. (in financing), effective (in time), and quality (in excellence).

Decision support systems can be used as a tool in determining the best administrative staff, several methods that can be used include ELECTRE [6], Analytical Hierarchy Process (AHP) [7], Profile Matching [8], TOPSIS [9], and SAW [10].

This research aims to develop a model of a decision support system, to determine outstanding academic administrative staff at the Sriwijaya State Polytechnic by using one of the methods in multi-criteria decision making (MCDM). The method used in this study is the Weighted Sum Model (WSM) as a method that is quite simple and easy to calculate and gives good weight in providing recommendations [3].

\section{LITEARUTER REVIEW}

\subsection{Decision Support System}

The system is a collection of sub-systems (elements) that are correlated with one another to achieve certain goals. Decision support system can be interpreted as a system designed to support management in decision making [2]. The decision support system selects a number of alternatives and predetermined criteria [5].

\subsection{Weighted Sum Model (WSM)}

The Weighted Sum Model (WSM) method is a very common method and is widely applied to assist in the decision-making process [3]. This WSM method is done by multiplying the weight of the criteria $(\mathrm{Wj})$ and the alternative value (Xij). This method is part of the MCDM (Multi-Criteria Decision Making) in evaluating the value of each alternative [4].

The settlement algorithm using the WSM method can be carried out in several stages as follows [2]:
1. Step 1: first identify the criteria and alternatives used in solving the problem.

2. Step 2: calculate the WSM-score. The formula used in this WSM method can be formulated in formula (1).

$$
A_{i}^{W S M-s c o r e}=\sum_{j=1}^{n} W_{j} X_{i j}
$$

$$
\begin{aligned}
& \text { Description: } \\
& \mathrm{n}=\text { number of criteria } \\
& \mathrm{Wj}=\text { weight of each criterion } \\
& \mathrm{Xij}=\text { matrix value } \mathrm{x}
\end{aligned}
$$

3. Step 3: do the ranking.

The difficulty of this method exists when the criteria used are not single-dimensional or multi-dimensional. In this problem, the existing criteria must be equated into the same dimension [11].

\section{IMPLEMENTATION AND RESULTS}

The application of the Weighted Sum Model (WSM) method is a very simple method. Some of the processes carried out in completing a decision support system using WSM can be described in the following steps.

\subsection{Determining Criteria and Alternatives}

In table 1 there are a number of criteria that are used as the basis for the decision-making process to determine academic administrative staff. In this model, 7 criteria are defined in accordance with the guidelines for selecting outstanding academic administrative personnel issued by the ministry.

These criteria include 1) educational qualifications, 2) track record of training/training activities, 3) track record of awards/achievements, 4) rank/class, 5) group tenure, 6) self-description value, and 7) individual work value. 
Table 1. Criteria Weight Value

\begin{tabular}{llc}
\hline No. & \multicolumn{1}{c}{ Name of Criteria } & Weight Value (Wj) \\
\hline 1 & Educational Qualifications (C1) & 0,1 \\
2 & Track record of training/training activities (C2) & 0,1 \\
3 & Track record of awards/achievements (C3) & 0,2 \\
4 & Rank/class (C4) & 0,1 \\
5 & Group Tenure (C5) & 0,1 \\
6 & Self-Description value (C6) & 0,2 \\
7 & Individual Work Value (C7) & 0,2 \\
\hline & & $\Sigma$
\end{tabular}

In accordance with the criteria that have been determined in Table 1, the next step is to determine the weight for each criterion.

Table 2. Criteria Weight Value of C1

\begin{tabular}{|c|c|c|}
\hline No. & Description & Weight Value \\
\hline 1 & Senior High School & 0 \\
\hline 2 & D1-D3 (Diploma) & 0,25 \\
\hline 3 & D4/S1 (Bachelor) & 0,5 \\
\hline 4 & S2 (Master) & 0,75 \\
\hline 5 & S3 (Doctor) & 1 \\
\hline
\end{tabular}

Table 2 is the normalized weight for the $\mathrm{C} 1$ educational qualification criteria, which describes the last level of education held by academic administrative staff.

Table 3. Criteria Weight Value of C2, C3, C6, C7

\begin{tabular}{llc}
\hline No. & Description & Weight Value \\
\hline 1 & Very Not Good & 0 \\
2 & Not good & 0,25 \\
3 & Pretty good & 0,5 \\
4 & Good & 0,75 \\
5 & Very good & 1 \\
\hline
\end{tabular}

Table 3 is a normalized weight for criteria $\mathrm{C} 2, \mathrm{C} 3$, $\mathrm{C} 6$, and $\mathrm{C} 7$ which has the same distribution of weight values for each criterion.

Table 4. Criteria Weight Value of C4

\begin{tabular}{|c|c|c|}
\hline No. & Description & Weight Value \\
\hline 1 & Group/Rank 1 & 0,25 \\
\hline 2 & Group/Rank 2 & 0,5 \\
\hline 3 & Group/Rank 3 & 0,75 \\
\hline 4 & Group/Rank 4 & 1 \\
\hline
\end{tabular}

Table 4 is the normalization of weights for the $\mathrm{C} 4$ Rank/Class criteria at the Sriwijaya State Polytechnic. As it is known that the state civil apparatus has a level of class 1 to 4 .

Table 5. Criteria Weight Value of C5

\begin{tabular}{|c|c|c|}
\hline No. & Description & Weight Value \\
\hline 1 & $<5$ year & 0 \\
\hline 2 & 6 up to 10 year & 0,25 \\
\hline 3 & 11 up to 15 year & 0,5 \\
\hline 4 & 16 up to 20 year & 0,75 \\
\hline 5 & $>20$ year & 1 \\
\hline
\end{tabular}

Table 5 is the normalization of weights for the $\mathrm{C} 5$ criteria for the tenure of the group. Of the several criteria that have been determined in Table 1 , the weights for $\mathrm{C} 3$ track record of awards/achievements, C6 
the value of self-description, and $\mathrm{C} 7$ the value of individual work get a weight value of 0.2 each to give the weight of the importance of these criteria in the selection of academic administrative staff with achievement.

\subsection{Calculating WSM Score}

Table 6 is an assessment made by the Decision Maker (DM) on 5 alternatives with 7 predetermined criteria.

Table 6. DM Preference Value for Alternatives

\begin{tabular}{cccccccc}
\hline Alternatives & C1 & C2 & C3 & C4 & C5 & C6 & C7 \\
\hline A1 & 0,25 & 0,5 & 0,5 & 0,5 & 0,25 & 0,75 & 1 \\
A2 & 0,5 & 0,75 & 0,5 & 0,75 & 0,25 & 1 & 0,75 \\
A3 & 0,75 & 0,75 & 0,5 & 0,75 & 0 & 1 & 0,5 \\
A4 & 0 & 0,5 & 0,75 & 0,75 & 0,25 & 1 & 0,75 \\
A5 & 0,5 & 1 & 1 & 0,75 & 1 & 1 & 0,75
\end{tabular}

From Table 6, a matrix as follows:

$$
X=\left|\begin{array}{ccccccc}
0,25 & 0,5 & 0,5 & 0,5 & 0,25 & 0,75 & 1 \\
0,5 & 0,75 & 0,5 & 0,75 & 0,25 & 1 & 0,75 \\
0,75 & 0,75 & 0,5 & 0,75 & 0 & 1 & 0,5 \\
0 & 0,5 & 0,75 & 0,75 & 0,25 & 1 & 0,75 \\
0,5 & 1 & 1 & 0,75 & 1 & 1 & 0,75
\end{array}\right|
$$

Furthermore, for the weight of each criterion that has been determined in the previous stage, the following values are obtained:

$\mathrm{W}=\left[\begin{array}{lllllll}0,1 & 0,1 & 0,2 & 0,1 & 0,1 & 0,2 & 0,2\end{array}\right]$

Based on formula (1) in the calculation of the WSM method, the following calculation results are obtained:

$$
\begin{aligned}
\text { A1 }= & (0,1 * 0,25)+(0,1 * 0,5)+(0,2 * 0,5)+(0,1 * 0,5)+ \\
& (0,1 * 0,25)+(0,2 * 0,75)+(0,2 * 1) \\
= & 0,6 \\
\text { A2 }= & (0,1 * 0,5)+(0,1 * 0,75)+(0,2 * 0,5)+(0,1 * 0,75)+ \\
& (0,1 * 0,25)+(0,2 * 1)+(0,2 * 0,75) \\
= & 0,675 \\
\text { A3 }= & (0,1 * 0,75)+(0,1 * 0,75)+(0,2 * 0,5)+(0,1 * 0,75) \\
& +(0,1 * 0)+(0,2 * 1)+(0,2 * 0,5) \\
= & 0,625
\end{aligned}
$$

$$
\begin{aligned}
\text { A4 }= & (0,1 * 0)+(0,1 * 0,5)+(0,2 * 0,75)+(0,1 * 0,75)+ \\
& (0,1 * 0,25)+(0,2 * 1)+(0,2 * 0,75) \\
= & 0,65 \\
\text { A5 }= & (0,1 * 0,5)+(0,1 * 1)+(0,2 * 1)+(0,1 * 0,75)+ \\
& (0,1 * 1)+(0,2 * 1)+(0,2 * 0,75) \\
= & 0,875
\end{aligned}
$$

\subsection{Ranking}

From the calculation of the WSM method, the result is that $\mathrm{A} 5>\mathrm{A} 2>\mathrm{A} 4>\mathrm{A} 3>\mathrm{A} 1$ so it can be concluded that A5 is the best alternative recommended by the decision support system as the best administrative staff. The final ranking of the WSM method can be seen in Table 7.

Table 7. Final Ranking

\begin{tabular}{ccc}
\hline Alternatives & Value Score & Ranking \\
\hline A1 & 0,6 & 5 \\
A2 & 0,675 & 2 \\
A3 & 0,625 & 4 \\
A4 & 0,65 & 3 \\
A5 & 0,875 & 1 \\
\hline
\end{tabular}

\section{CONCLUSION}

Based on the research that has been done, it can be concluded that the model can be used to help determine the academic administrative staff with achievement at the Sriwijaya State Polytechnic. The WSM method does not consider the benefit and cost criteria, so the weight value gives good calculation results.

\section{REFERENCES}

[1] Direktur Jenderal Sumber Daya IPTEK dan Perguruan Tinggi, 2019, Pedoman Pemilihan Tenaga Administrasi Akademik Berprestasi Tahun 2019, Kementrian Riset, Teknologi dan Pendidikan Tinggi.

[2] D. Nofriansyah, S. Defit, 2020, Multi Criteria Decision Making (MCDM) pada Sistem Pendukung Keputusan, Yogyakarta, Deepublish.

[3] T. Mitra and K. Ozbek, 2021, Ranking by Weighted Sum, Economic Theory, 7, pp. 511-532.

[4] I. B. Al-Bayati, S. S. Al-Zubaidy, 2020, Applying the Analytical Hierarchy Process and Weighted Sum Model for Small Project Selection in Iraq, IOP Conf. Ser.: Mater. Sci. Eng. 671012158.

[5] Budiharjo, A. P. Windarto, A. Muhammad, 2017, Comparison of Weighted Sum Model and Multi 
Attribute Decision Making Weighted Product Methods in Selecting the Best Elementary School in Indonesia, International Journal of Software Engineering and Its Applications, 11(4), pp. 69-90.

[6] S. Sirait, D. Y. Saragih, H. Sugara, M. Yunus, Sumaizar, M. A. Hanafiah, V. M. M. Siregar, I. Indrawan, U. Anwar, D. Defliyanto, 2021, Selection of the Best Administrative Staff using Elimination Et Choix Traduisant La Realite (ELECTRE) Method, J. Phys.: Conf. Ser. 1933 012068 .

[7] A. L. Hananto, B. Priyatna, A. Fauzi, A. Y. Rahman, Y. Pangestika, Tukino, 2021, Analysis of the Best Employee Selection Decision Support System using Analytical Hierarchy Process (AHP), J. Phys.: Conf. Ser. 1908012023.

[8] M. R. Fachrizal, N. R. Radliya, A. Manik, 2019,
Development of E-Recruitment as A Decision Support System for Employee Recruitmen, IOP Conf. Ser.: Mater. Sci. Eng. 662022018.

[9] R. Rahim, S. Supiyandi, A. P. U. Siahaan, T. Listyorini, A. P. Utomo, W. A. Triyanto, Y. Irawan, S. Aisyah, M. Khairani, S. Sundari, K. Khairunnisa, 2018, TOPSIS Method Application for Decision Support System in Internal Control for Selecting Best Employees, J. Phys.: Conf. Ser. 1028012052.

[10] M. Saputra, O. S. Sitompul, P. Sihombing, 2018, Comparison AHP and SAW to promotion of Head Major Department SMK Muhammadiyah 04 Medan, J. Phys.: Conf. Ser. 1007012034.

[11] Ramon San Cristobal Mateo, Jose, 2012, MultiCriteria Analysis in the Renewable Energy Industry, London : Springer. 